\title{
A GUIDE TO SELECTED COMMONWEALTH ARCHIVES (CANBERRA AND DARWIN) RELATING TO ABORIGINES
}

\author{
Rosslyn Fraser
}

In 1977 a brief note on a group of Commonwealth records appeared in the first volume of Aboriginal History. ${ }^{1}$ The resulting interest in my article encouraged me to apply to the Australian Institute of Aboriginal Studies for a research grant to produce a more extensive guide to Aboriginal material in Commonwealth Archives. An interim draft guide based on two years of work is now available at the A.I.A.S. Library and at the Australian Archives Reference and Guide Room. The guide is intended for publication when completed. In the meantime I would appreciate comments from researchers concerning the form and content of the interim draft guide.

\section{The records}

Every government activity produces records of some kind. When these records cease to be used administratively, and if they are intended to be kept permanently, they become 'archives'. Under the Australian government's present access policy, most records over thirty years old (i.e. up to the end of 195I, and, from 1 January 1983, up to the end of 1952) are open to the public. The guide thus includes records to the end of 1951 and some records from 1952 will be added to the final guide when they become available in 1983 .

The records described in the guide are in the Northern Territory and ACT Branches of Australian Archives in Darwin and Canberra respectively. They are some of the records kept in the conduct of their business, and themselves constituting part of that business, by a variety of Commonwealth government agencies ${ }^{2}$ the functions of which have in some way impinged on Aborigines' lives. (Agencies so far included are given in the Appendix.) They relate mostly to the Northern Territory, for which the Commonwealth became responsible in 1911, and they include some papers from the period of South Australian administration of the Territory (1863 to 1911; most papers arising from the South Australian administration are in the State Archives Section of the State Library of South Australia.) There is also, however, some material relating to the States, and work in 1982/83 is expected to reveal a larger proportion of material with significance to people in the States than has so far emerged.

Just about anything can constitute a record if it is made or kept for that purpose. Different types of record so far represented in the material described in the guide include cards, volumes, photographs, maps, plans, charts, sketches, objects, notebooks, published material, unfiled papers, forms and files, which may contain any of the foregoing. It is hoped that the completed guide will include details of some films and sound tapes, and possibly other forms of material.

The nature and level of the transactions of which the records are the evidence are even more varied than their physical form. Papers (and other forms of record) covered by the guide deal with a range of matters from, for example, national policy to the payment of a day's wages to a particular person. Unfortunately for current research, most of the papers relating to minor transactions such as the latter have been destroyed as a matter of course, and some major, as well as less inherently important, material has similarly been destroyed or otherwise lost.

- Australian Archives, Canberra. 'Records of the Department of External Affairs (I), 1901-1916, relating to Aborigines', Aboriginal Histon, 1(2), 1977:106-110.

$A$ Commonwealth agency is defined for the purposes of the guide as a separate administrative unit of a government, having its own independent record-keeping system. An agency can be of any size or complexity, and may administer one or many function. 
Researchers intending to use material covered by the guide should write requesting applications for access and search tickets or call at the appropriate office:

Material in Canberra: Regional Director (ACT), Australian Archives,

P.O. Box 447 , Belconnen ACT 2617.

(Tel. (062) 421411 )

Material in Darwin: Regional Director (NT), Australian Archives, PO Box 293, Darwin NT 5794.

(Tel. (089) 85 2222)

Applications require the sponsorship of a person on the electoral roll (who need not hold any academic or public position), so it is best to get the application forms in advance. Your application should also give a clear and precise description of your area of interest, to enable staff to give you informed help. The same procedures apply to Australian Archives Branches in all State capitals and in Townsville, which also have relevant holdings. ${ }^{3}$

\section{Why use government records?}

Many Aborigines are very aware of the value of having access to records about themselves or with a bearing on their situation. In the attempt of the rest of Australian society to control and regulate every aspect of their lives, one of the essential weapons for enforcing control has been pieces of paper. Whether Aborigines live in isolated areas or in towns and cities, and whatever their age group, they have been subject to constant bureaucratic and other intrusions. Their lives have been full of questions and full of requirements to supply information, make statements, fill out forms, fill out more forms, and present themselves at government agencies. Pieces of paper have at various times been referred to as authority in arresting people, in gaoling them, taking away their children, evicting them, keeping their property and earnings from them, depriving them of employment, forcing them into compounds, keeping them in these compounds after dark, confining them in institutions, interfering in their marital relationships, preventing them from drinking liquor, isolating them from their country, threatening them, and according them or disqualifying them from benefits automatically enjoyed by the rest of the community.

Aborigines are also well-acquainted with the frustrations of trying to get access to information about them or originally provided by them. There are illustrations of both aspects of the process in the film Wrong side of the road. Leslie is shunted from agency to agency, and refused even the possibility of access to his natural mother's name without his initiating action just to try to obtain a Supreme Court Order. Even his adoptive parents conceal the relevant piece of paper from him, and he has to steal it to have the mere chance to establish his identity. The Truant Officer, when she arrives to track down George (shown by the school records to be consistently truant), brings with her a clipboard on which she records not facts but value judgments of a kind commonly used before tribunals as evidence that children should be taken from their families. Vonnie refers to the absurdity of the classification of two of her children, born under former South Australian legislation, as having $\mathbf{x}$ parts Aboriginal blood. The police who arrest Ronnie and his mate no doubt have existing Australia-wide computerised records scanned for any previous convictions that they might have. And so on. It is no wonder that Aborigines appreciate the uses of records.

Aborigines are also, of course, quite aware of the short-comings of the records, which are, after all, the artefacts of a bureaucracy informed by and serving Anglo-Australian values. At their best and most objective, records must remain culture-bound, circumscribed

3 The addresses of these branches and other major archival institutions are listed in: H.J. Gibbney, 'Archives', in Barwick, Diane, Michael Mace and Tom Stannage eds. Handbook for Aboriginal and Islander history. Canberra, 1979: 5-12. 
by the values and perceptions of their recorders; at their worst, they contain deliberate distortions. The greater part of them is liable to be beset by poor observation, misrecording and misinterpretation.

The archives are nonetheless often the sole record of the transactions recorded in them. They have additional value, particularly in the period dealt with by the guide, in that their recorders generally did not imagine that they would ever become the subject of public, let alone Aboriginal, scrutiny. As a result of this they can often provide an unselfconscious picture of what was done, observed and thought by one set at least of the participants in post-contact history. They are significant not only because they are one essential source in purting together more realistic versions of this history (by both Aborigines and non-Aborigines) than have been available until recently, but because they can have an immediate and compelling bearing on people's lives. What W.T. Hagan says of North American Indians and their access to records can be extrapolated to Australian Aborigines' situation now:

.... for the Native American this is more than just some intellectual game. What is at stake for the Indian is his historical identity, and all that can mean for self-image and psychological well-being.

At stake also is the very existence of tribes, and the validity of their claims to millions of acres of land and to compensation for injustices suffered in earlier transactions with the federal and state governments."

Both policy records and documentation of day-to-day administration can have evidentiary value for individuals and communities. Their usefulness has been shown in evidence given for land claims made under the Aboriginal Land Rights (Northern Territory) Act 1976, which of course emanates from the same cultural basis as the records themselves. While Aboriginal and anthropological evidence has been most important, Commonwealth and South Australian government records (both archives and, in the former case, current records), and private papers, have provided a wide range of information. Such documents may give clues to the post-contact history of claim areas, and the historical relations between Aboriginal groups and between Aborigines and others. Documents may mention traditional practices, languages, and cultural innovation. They may also contain genealogies, evidence of individual and group attachments to the land, and explanations for some people not having been able to maintain an unbroken association with their land. Written materials may describe the effects of European settlement on the environment and on Aboriginal economy and social organisation; demographic change; health; Aboriginal resistance to, and accommodation with, incursions; institutionalisation and its effects; and the Anglo-Australian legal status of the land in question. The Northern Territory government recognized the importance of records in the determination of claims when it amended the Evidence Act in 1981 to restrict access to government documents to be used in court cases. The government strongly denied that its action was intended to impede the hearing of the Kenbi claim following a High Court verdict enabling the Aboriginal Land Commissioner to hear evidence on this claim.

Aboriginal people in the States will also find information in State government and other records which can contribute to their own sense of identity. When legislation for land rights is introduced in the States, archival materials will be useful in satisfying the requirements of tribunals.

There are other areas of Anglo-Australian law, too, where recourse to records can at least raise the possibility of entitlements previously denied, and may sometimes be instrumental in resolving such issues favourably. A recent example of the former was proclaimed in an article in The Age: 'Blacks may act on $\$ 60 \mathrm{~m}$ in war back pay claim.' This possibility has arisen from an article by Major Robert $\mathrm{Hall}$, based on archival and other 
sources. ${ }^{6}$ It may or may not prove feasible to pursue this particular question through the courts or at a political level, but it has at least been raised and publicised. If it did prove feasible, Forces' personnel, policy and other records would be essential to its determination.

In New South Wales, in the context of the excellent work done by the Aboriginal Children's Research Project, Linkup, and the Task force for Aboriginal Children, and of Aboriginal concern about the Community Welfare Bill, the New South Wales Branch of the National Aboriginal Conference passed a resolution in January 1982 which said in part:

State welfare departments hold information about Aboriginal children who have been removed from their families over the years. This information rightly belongs to the Aboriginal communities. It is recommended that arrangements be made to give Aboriginal people access to such information regarding their relatives, through the vehicle of appropriate Aboriginal organisations such as Aboriginal children's services in each State.

For some people of all age groups in New South Wales, these records may provide the sole link with family, community and identity, as with Leslie Stevens in Wrong side of the road.

These are examples of uses within some kind of legal framework to which archival and current records can be put, but there are many others. While the information in written records may or may not be correct or appropriate from either an Aboriginal or a nonAboriginal viewpoint if it is known about it can be evaluated. When the information about known or remembered facts and events is 'correct', and compatible with memory, it can be an appreciated reminder about places, people or events. Whether correct or not, it may explain the outcome of situations, or the behaviour of non-Aboriginal participants, both of which may previously have been incomprehensible and for that reason alone unsettling. If it is incorrect, or biased, when the record is available it is possible for people to give an alternative account, if that is important to them. At times, such information is all that remains about the matters it concerns, and is important simply for that reason.

As well as records which directly concern Aborigines and administrative dealings with them, many types of records can be useful for Aboriginal history. For example, in studies contributing to reconstruction of the pre-contact history of western New South Wales, Jeannette Hope, Brenda Jacobs and Jane Balme are using records of various government agencies (such as the Water Resources Commission) as well as early descriptions written by European explorers and 'settlers'. Their work is helping to establish how long Aborigines have occupied this part of New South Wales, and how they lived at different times in the past. A rchaeological research has disproved the old view that Aborigines have occupied Australia for only a few thousand years. Some of Jane Balme's findings suggest that Aborigines may have been using fishing nets at a period long before there is evidence for that kind of technology elsewhere in the world. Archival documents can assist in the interpretation of other kinds of evidence in a way which is of value not only to world archaeology but to present-day Aborigines in their assertion of their identity. Written record's can provide evidence about the continuity of their society, their technological and cultural development, and the length of their occupation of this continent.

\section{The guide}

The guide attempts to make known, and provide easier access to, Commonwealth records which constitute a basic resource for Aboriginal history. The framework of the guide is an archivally conventional one: records are described in relation to their provenance, that is, in relation to the agency or agencies which produced or kept them. The elements of description and the terms used are taken directly from the

6 RA. Hall, 'Aborigines and the army: the second World War experience', Defence Force Joumal, $(24)$, September-October 1980:28-41. 
Australian Archives documentation system. Within this provenance-oriented framework I have tried to assist researchers by annotating some entries (see below). If possible, the final guide will include a name/place/subject index to the text, to entries at all levels of description, and to the annotations. (Annotation and content indexing are levels of description which archival institutions with large holdings cannot generally attempt. Indexing of archival content is rather like trying to include every possible index entry in every book in the library in the library's catalogue.)

An introduction to the existing draft defines terms and explains how the guide.works. This will probably be expanded eventually to include discussion of how records are made and kept, and how they can be useful to Aborigines and to other researchers.

The body of the guide is in two parts, the first dealing with records in Australian Archives, ACT Branch, and the second with records in the Northern Territory Branch in Darwin. Each part is divided into two sequences. The first lists some of the Commonwealth Agencies (see footnote 2 and Appendix) and Commonwealth Persons which, or who, have had functions in some way giving rise to records relevant to Aborigines. With each Commonwealth Agency or Person entry there is a summary list of at least some of its record series or accessions ${ }^{7}$ which contain (or, occasionally, are likely to contain) relevant records. Where possible, there is also a brief administrative history or biographical note. For the one hundred agencies and fifteen people so far included, approximately four hundred record series/accessions have been listed.

The summary series/accession entries in this sequence are noted to show whether additional information about them occurs in the second sequence, and, if so, what level of information is given.

The second sequence in each part is a numerical list of all series/accessions referred to in the first sequence, with any additional information. Each entry gives the series/ accession title, date range, and all agencies which had a hand in recording it. Where it has been both desirable and possible, additional information has been included which may relate to its physical form, its history, previous and subsequent series, its content, and existing finding aids to it created by the agency recording it and/or by Australian Archives.

It is also in this sequence, under the series/accession entries, that select lists of some record items (e.g. files in a file series, photographs in a photograph series) have been included where possible. At present (November 1982) there are about 87 such item lists, with about 3,500 items listed.

Approximately 1,000 of the entries for the items listed in this way have been annotated to give some indication of the range and type of content in the files. There is a serious danger that such annotations, which are not intended to convey the full content or significance of any file, may conceal as well as reveal information, particularly when a controlled vocabulary has not been developed. They have been included, however, because users' needs in the present social, legal and political situation require that at least some specific information can be quickly retrieved. They are also aimed at seducing and cajoling people, who otherwise might not use the records, into doing so, and into using archival collections in general. The important thing is that researchers realise that annotations are partial, necessarily subjective, and based on only a hasty inspection of files.

There is no space here to discuss why the agencies, series and items included have been chosen over others, or why some have been annotated and others not. Selection has been basically a pragmatic process, in response to numerous variables. As with annotations, researchers should recognise that the selection of agencies, series and items far from represents everything available. However, an initial reference to the selection as it

The term 'record series' here designates the totality of records within a particular numerical or ocher symbolic sequence, cr which have been accumulated for the same purpose or following the same format. 'Accession' refers to a discrete collection of records transferred to archival custody by an agency; an accession may consist of one or more series, or parts of one or more series. 
stands makes a wider search possible, by greatly reducing the time and effort researchers must individually put into the areas which it touches on and leaving them free to pursue other avenues.

One thing that I hope the guide will do when it is eventually published is to demystify archives, and encourage people, particularly Aborigines, to use not only the Australian Archives' holdings it describes but also the numerous other archival and manuscript collections within and outside Australia which contain a wealth of relevant government, business and personal papers.

AUSTRALIAN INSTITUTE OF ABORIGINAL STUDIES

\section{APPENDIX}

\section{Commonwealth Agencies Included (ACT)}

Attorney General's Department
Australian Institute of Anatomy
Australian War Memorial
Cabinet Secretariat [I]
Crown Solicitor's Office
Defence [II]], Department of
* External Affairs [I],
Department of
Federal Capital Commission
Federal Executive Council
Governor-General's Office
Health, Department of
"Home Affairs [II],
Department of
"Home and Territories,
Department of

$1901-$
$1931-$
$1925-$
$1901-1968$
$1903-$
$1942-$
$1901-1916$
$1925-1930$
$1901-$
$1901-$
$1921-$
$1928-1932$
$1916-1928$

Information, Department of

Interior [I], Department of the

"Interior [II], Department of the

Investigation Branch

Jervis Bay Office

Pensions and Maternity Allowance Office

Prime Minister's Department

$1939-1950$
$1932-1939$
$1939-1972$
$1919-1946$
$1937-$
$1912-1948$
$1911-1971$
$1919-1920$
$1939-1972$
$1951-1968$
$1939-1946$

* Departments with administrative responsibility for the Northern Territory

Commonwealth Agencies Included (Northern Territory)

Administrator, Office of the

Administrator, Office of the

Administrator, Office of the - . District Office, Alice Springs

Clerk of Courts, Darwin

Courts Office of the Northern Territory

Crown Law Office, Darwin

Gaol and labour Prison, Alice Springs

Gaol, Palmerston, and Darwin Gaol and Labour Prison

Government Resident [of North Australia], Office of the

Half-Caste Institution, Alice Springs ('The Bungalow') and, Half-Caste Institution Balaklava, South Australia

Health, Department of, Northern Territory Divisional Office ('Northern Territory Medical Service")

Health and Aboriginals Branch
$1911-1927$

1931 -

1937-1942;

1945-?

$1924-1950$

1950-1962

?1922-

1938 -

1872-1942.

1947-?

1974 -

1927-1931

$1942-1946$

1932-19??

1939-?1978

$1927-1930$
Land Office, Darwin

Lands and Mines Department

Lands and Survey Branch

Lands and Survey Department [I]

Lands and Surveys Deparment [II]

Lands Department

Local Court of Anthony's Lagoon

Medical Officer, Alice Springs

Medical Service and Health Branch (North Australia Medical Service)

Medical Service, Health and Aboriginals Branch, (Northern Territory Medical Service')

Medical Service, Health and Aboriginals Branch, Patrol Officer, Alice Springs and Jay Creek

Mines [I], Department of

Mines Branch [I] (head office)

Native Affairs Branch (head office)

Native Affairs Branch, Alice Springs

North Australia Commission

Police, Office of Commissioner of, Alice Springs
$1869-1912$

$1921-1925$

$1931-1972$

1914-1921

1925-1931

1912-1914

1929-1943

?

1930-1931

1931-1939

1936-1942

1912-1921

1928-1968

$1939-1955$

1927-1931

1927-1928 
Police, Office of the Commissioner, · 1924-1927 of Darwin

Police Inspector's Office [1] 1869-1924

Police, Office of Inspector of [II] I I928-1931 North Australia

Police, Office of Superintendent of 1931-1964

Police Camp, Birdum ?

Police Stations:

Adelaide River (1946)

Alice Springs $\quad(1886)-1927$

1928-1942

$1945-$

Alice Well

Anthony's Lagoon

$1912-(1928)$

Arltunga

Barrow Creek

Borroloola

Bow Hills

Brocks Creek

1889-?

? -1944

1926-1945

1886-?

? 1913-1919

1898-?

Charlotte Waters

Daly River

Darwin

Emungalen

Finke

1930-1938

?

$1942-$

?

1938 -

Frew River

Gordon Creek

Groote Eylandt

Hammond

Harts Range

Hatches Creek

Illamurta

Katherine

Lake Nash

Larrimah

Maranboy

Mataranka

Nectar Brook

Newcastle Waters

Pine Creek

Platelayers' Camp

Powell's Creek

Rankine River

Roper River

Tennant Creek

Timber Creek

Wave Hill

Yardea

1918-1921

1894-1898

?

?

$1944-$

(1937-1950)

by $1897-1912$

1886 -

?

1944 -

by $1917-$

1928-

?

1913-1951

1873 -

1928-1929

1889-1913

1911-1963

1889-

1898 -

$1919-$

?

1911-1924

1912-1914 